\title{
Рекомендації щодо забезпечення митної безпеки на основі адаптації до інтегрального рівня митної небезпеки
}

\author{
Володимир Богданович ${ }^{1}$ А; Іван Марко * 2 А; \\ Тетяна Яковлєва ${ }^{3}$ А; Сергій Саєнко ${ }^{4}$ А \\ А Центральний науково-дослідний інститут Збройних Сил України, м. Київ, Україна \\ в Державна митна служба України, м. Київ, Україна \\ с Національний університет оборони України імені Івана Черняховського, м. Київ, Україна
}

Received: December 5, 2021 | Revised: December 10, 2021 | Accepted: December 30, 2021

DOI: $10.33445 /$ sds.2021.11.6.8

\begin{abstract}
Анотація
В статті розглядаються рекомендації щодо забезпечення митної безпеки на основі адаптації до інтегрального рівня митної небезпеки. Сучасне і майбутнє безпекове середовище характеризується широким спектром небезпек і загроз, загостренням боротьби за доступ до новітніх високих технологій, ресурсів та ринків збуту, що деструктивно впливає на економічну та митну безпеку держави. Пропонується провести декомпозицію небезпек та загроз за сферами прояву, побудувати трирівневу модель оцінювання за технологією методу аналізу ієрархій і оцінити інтегральний рівень митної небезпеки на вибраний момент часу. Далі експертним шляхом визначаються відмітні рівні та пороги митної небезпеки, зокрема: рівень (поріг) взаємовигідної співпраці; рівень (поріг) підвищеної митної небезпеки; рівень (поріг) передкризової митної обстановки; рівень (поріг) кризової митної обстановки. Це дає змогу системі забезпечення митної безпеки адаптуватися до величини інтегрального рівня митної небезпеки шляхом вибору того чи іншого режиму функціонування системи: режиму взаємовигідної співпраці; режиму підвищеної готовності; режиму передкризової митної обстановки, антикризового режиму. При цьому підвищується обґрунтованість управлінських рішень в системах забезпечення митної та економічної безпеки, підвищується оперативність реагування на небезпеки і загрози митного та економічного характеру, забезпечуються умови для більш раціонального використання наявних в системі людських та інших ресурсів, і в цілому підвищується ефективність забезпечення митної і економічної безпеки держави.
\end{abstract}

Ключові слова: митниця, небезпека, загроза, митні органи.

\section{Постановка проблеми}

На економічний розвиток держави визначально впливають зовнішньоекономічні зв'язки нашої країни, ефективна експортно-імпортна діяльність вітчизняних господарюючих суб'єктів, висока конкурентоспроможність національної економіки, мобільність наших співгромадян, ефективне нормативно-правове забезпечення митної діяльності. Великого значення набуває ефективність імплементації національних інтересів, а також інтересів юридичних і фізичних осіб, галузей і регіонів у митній сфері. А відтак, постає нагальна потреба у забезпеченні митної безпеки і мінімізації економічних збитків із-за недосконалості митної сфери. Вирішенню цієї проблеми також перешкоджають відсутність обґрунтованої митної доктрини і політики, недосконалість процедур митного регулювання і контролю, низький рівень

\footnotetext{
${ }^{1}$ доктор технічних наук, професор, головний науковий співробітник, e-mail: bogdnr11@gmail.com, ORCID: 0000-0003-0481-9454

2 * Corresponding author: головний державний інспектор, e-mail: i.marko94@gmail.com, ORCID: 0000-0002-7208-3963

${ }^{3}$ слухач кафедри економіки та фінансового забезпечення, e-mail: yaktan@ukr.net, ORCID: 0000-0002-0595-2727

${ }^{4}$ слухач кафедри економіки та фінансового забезпечення, e-mail: saenkocznp@ukr.net, ORCID: 0000-0002-6713-1545
} 


\begin{tabular}{lllllr}
\hline впровадження & \multicolumn{1}{c}{ сучасних } & інформаційних & доцільно розробити адаптивну до \\
технологій, & низька & результативність & інтегрального рівня митної небезпеки \\
здійснюваних заходів з протидії корупційним & систему, а також впровадити в алгоритми ї̈ \\
діянням у митній справі. Для успішного & функціонування адаптивні & ресурсно- \\
усунення зазначених деструктивних чинників & забезпечені режими роботи.
\end{tabular}

\section{Аналіз останніх досліджень та публікацій}

Проблематику митної безпеки досліджували такі вітчизняні й зарубіжні науковці, як: І. Бережнюк [1], М. Губа [2], О. Джумурат [3], Є. Додін [4], О. Камчатна [5], С. Коляда [6], М. Кочубей [7], С. Куряков [8], М. Левко [9], В. Мартинюк [10], І. Новосад [11], П. Пашко [12] та інші. Утім на сьогодні відсутні усталені погляди на методологію, Постановка завдання

У розглянутих публікаціях основна увага приділена методичним підходам до підвищення ефективності управління митною безпекою в системі забезпечення митної та економічної безпеки України, при цьому автори розглядають лише організаційні механізми. Методологічні аспекти підвищення ефективності управління забезпеченням митної безпеки за рахунок послідовність, обсяги, зміст та висновки 3 оцінювання митної обстановки, відсутні рекомендації щодо формування системи показників оцінювання інтегрального рівня митної небезпеки та адаптації режимів роботи митних органів до інтегрального рівня митної небезпеки в умовах сучасних загроз.

\section{Виклад основного матеріалу}

На митну складову в економічній сфері покладається одне із відповідальних завдань щодо наповнення державного бюджету. Крім того для успішної інтеграції до Європейського співтовариства митна політика України повинна бути спрямована на функціональне наближення своєї структури та діяльності до аналогічних митних структур країн - членів Європейського співтовариства, що покращуватиме результати зовнішньоекономічної діяльності (ЗЕД) та сприятиме більш ефективній імплементації державних інтересів в економічній сфері. Критерієм ефективності митної політики виступає безперебійне переміщення вантажів і громадян $з$ належною швидкістю та якістю, що потребує насамперед удосконалення організації митного контролю.

Ефективний митний контроль згідно визначених митною політикою та законодавчими актами функцій повинен забезпечувати протидію транскордонній злочинності і тероризму, виявлення нелегальних товарів, наркотиків, вибухових речовин, компонентів ядерної і хімічної зброї, що позитивно відображатиметься також на забезпеченні воєнної, продовольчої, екологічної і радіологічної безпеки та інших складових національної безпеки держави [13]. Звідси слідує, що основним інструментом усунення або деескалації небезпек, загроз і інших деструктивних чинників, що впливають на рівень митної безпеки держави, виступає митний контроль. Основним обмеженням згідно положенням чинної митної політики, якому має відповідати митний контроль, це - в сучасних умовах значного збільшення обсягів зовнішньої торгівлі, ефективність митного контролю має постійно зростати, підвищуючи 
при цьому рівень захисту національних інтересів та знижуючи рівень економічних збитків держави. Зазначені обставини зумовлюють необхідність удосконалення алгоритмів діяльності митних органів, віднесення до їх компетенції нових завдань, спрямованих на досягнення стратегічних цілей держави. Практична реалізація запропонованого напряму досягнення більш високого рівня митної безпеки може бути здійснена шляхом адаптації процесу функціонування системи забезпечення митної безпеки до інтегрального рівня митної небезпеки [14], узагальнена модель якого наведена на рис. 1.
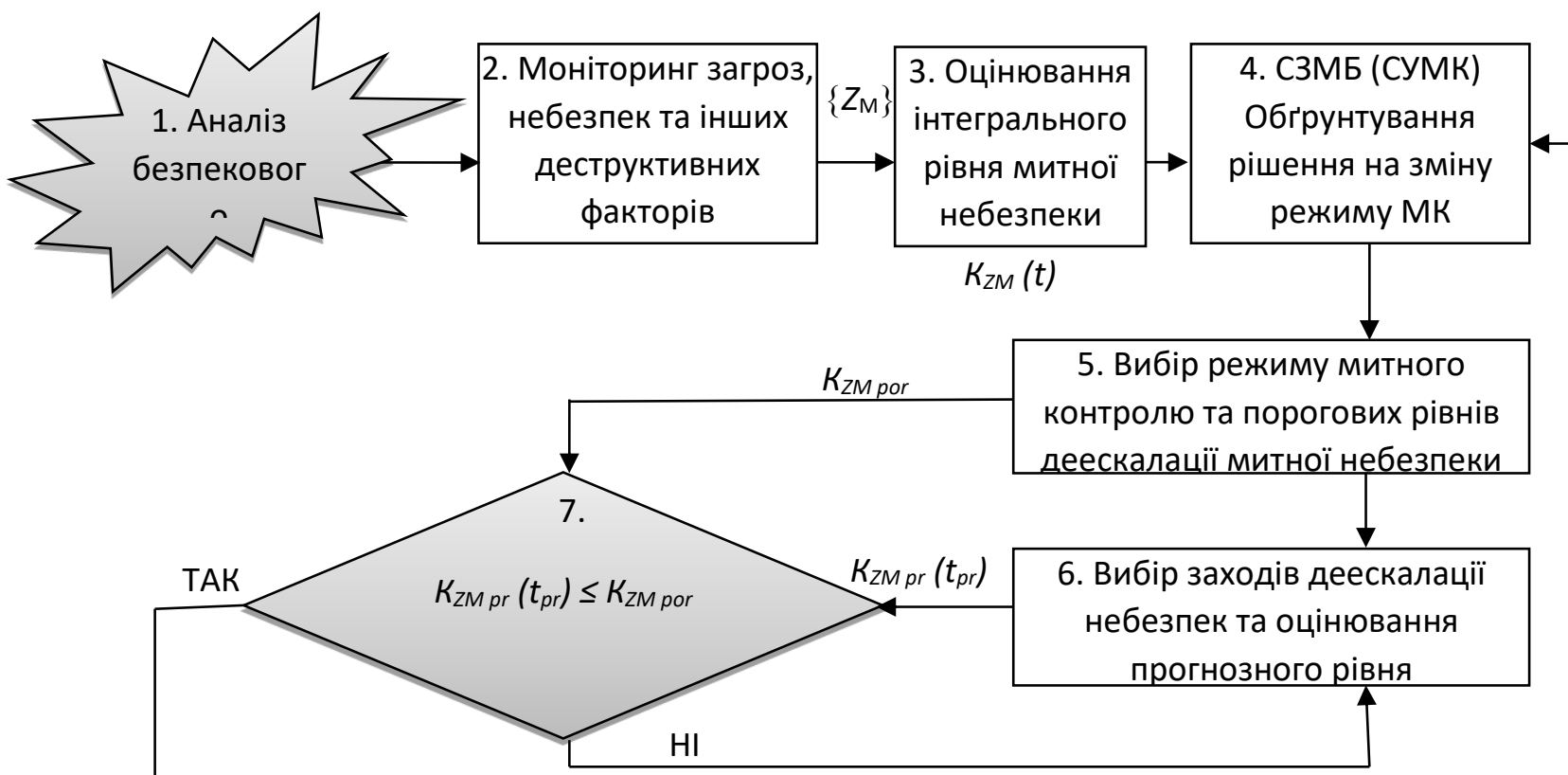

Рисунок 1 - Узагальнена модель процесу забезпечення митної безпеки на основі адаптації до інтегрального рівня митної небезпеки (загрози)

Узагальнена модель процесу адаптації містить сім часткових процесів. Розглянемо основні операційні завдання для кожного часткового процесу.

Перший частковий прощес: аналіз безпекового середовища. На жаль, дефініція безпекового середовища на цей час у нормативно-правових документах не визначена. У цій публікації під безпековим середовищем будемо розуміти геополітичну, політико-дипломатичну, воєнну, економічну, інформаційну та інші сфери, де зароджуються, існують, накопичуються або проявляються сприятливі умови або небезпечні явища, потенційні та реальні загрози реалізації національних інтересів, у яких держава реалізує свою політику національної безпеки, взаємодіє 3 міжнародними структурами безпеки, стратегічними партнерами, союзниками, іншими інститутами й організаціями В інтересах забезпечення свого сталого розвиту на певному часовому інтервалі [15]. Безпекове середовище будемо розглядати 3 точки зору забезпечення економічної безпеки та їі основної складової - митної безпеки.

У ході проведення комплексного аналізу митної обстановки мають бути виявлені найнебезпечніші фактори та тенденції, що визначально впливатимуть на ефективність забезпечення митної безпеки на вибраний часовий інтервал.

Майбутнє безпекове середовище у світі та довкола України характеризуватиметься збереженням високої динаміки міжнародних 
та регіональних процесів, посиленням нестабільності у світі та виникненням нових зон напруженості. Економічно розвинені держави прагнутимуть максимально реалізувати національні інтереси, у тому числі 3 використанням економічних інструментів.

Крім того, для майбутнього безпекового середовища характерними рисами залишатимуться наявність екстремізму, міжнародного тероризму, транснаціональної організованої злочинності, боротьби за доступ до новітніх високих технологій, ресурси та ринки збуту, а також посилюватимуться в ході цієї боротьби протиправні дії в економічній сфері.

Серед важливих для національної безпеки питань $€$ виявлення та деескалація небезпек і загроз у визначальних сферах національної безпеки, перш за все у економічній, на яку суттєвий вплив здійснює глобалізація, яка істотно впливає на економіку держав, посилює їх взаємозалежність, загострює суперництво за доступ до енергетичних ресурсів. Разом з позитивними чинниками глобалізація провокує збільшення нерівності у розподілі світових ресурсів, призводить до турбулентності міжнародних потоків капіталу та пов' язаних з цим протиріч і криз. В умовах поглиблення розриву в розвитку країн проблемою залишається поділ світу на багатий центр і бідну периферію. Негативним наслідком глобалізації $\epsilon$ політична нестабільність, проявами якої $\epsilon$ збільшення низки недієздатних, невизнаних держав та держав, які деградують, або таких, що не відбулися. У багатьох країнах спостерігається криза влади, стримується розвиток демократичних процесів, набирають сили сепаратистські рухи. Ситуація погіршується також унаслідок кризових процесів у макроекономіці. Очікується подальше загострення конкуренції, боротьба за збереження та розширення зон впливу, що деструктивно впливає на митну обстановку навколо України.

Важливим чинником формування зовнішньополітичних умов, що впливатимуть на рівень економічної безпеки України, залишатиметься співробітництво 3 провідними світовими та регіональними міжнародними організаціями, підтримання взаємовигідних партнерських відносин на двосторонньому рівні.

За цих умов сильніші держави намагаються нав'язувати свою волю слабкішим партнерам всупереч нормам міжнародного права, у тому числі й у взаємовідносинах митних органів. Це може призвести до посилення небезпеки неконтрольованого розповсюдження ядерної зброї та їі носіїв, матеріалів для їх виробництва, технологій подвійного призначення; поширення тероризму (у тому числі кібертероризму), піратства, організованої злочинності, нелегальної міграції, незаконної торгівлі зброєю та наркотиками, торгівлі людьми, що сприятиме зростанню міжнародної нестабільності.

Другий частковий процес: моніторинг загроз, небезпек та інших деструктивних факторів. Підвищення ефективності стратегічного планування забезпечення економічної безпеки - важлива проблема органів державної влади, актуальність якої постійно зростає. Це зумовлено необхідністю постійно мати інформацію про загрози та небезпеки, їх характер, рівень, масштаб, тенденції зміни. Вказані завдання покладаються на систему моніторингу економічної обстановки, яка має працювати в інтересах системи забезпечення національної безпеки.

Стратегічний моніторинг загроз $є$ основою стратегічного планування в системах економічної, митної та інших системах забезпечення національної безпеки. Основним завданням моніторингу пропонується вважати отримання інформації щодо переліку загроз, небезпек та інших деструктивних факторів $\{Z\}$, їх характеру, якісних і кількісних характеристик для відповідного реагування системами забезпечення митної та економічної безпеки. 
Третій частковий процес: оцінювання інтегрального рівня митної небезпеки $K_{Z M}(t)$. Цей частковий процес здійснюється 3 використанням удосконаленого методу аналізу ієрархій (MAI) та побудованій на його основі моделі М7 [15].

Для цього будується трирівнева модель оцінювання, рис. 2, та вводяться вихідні дані в модель М7.

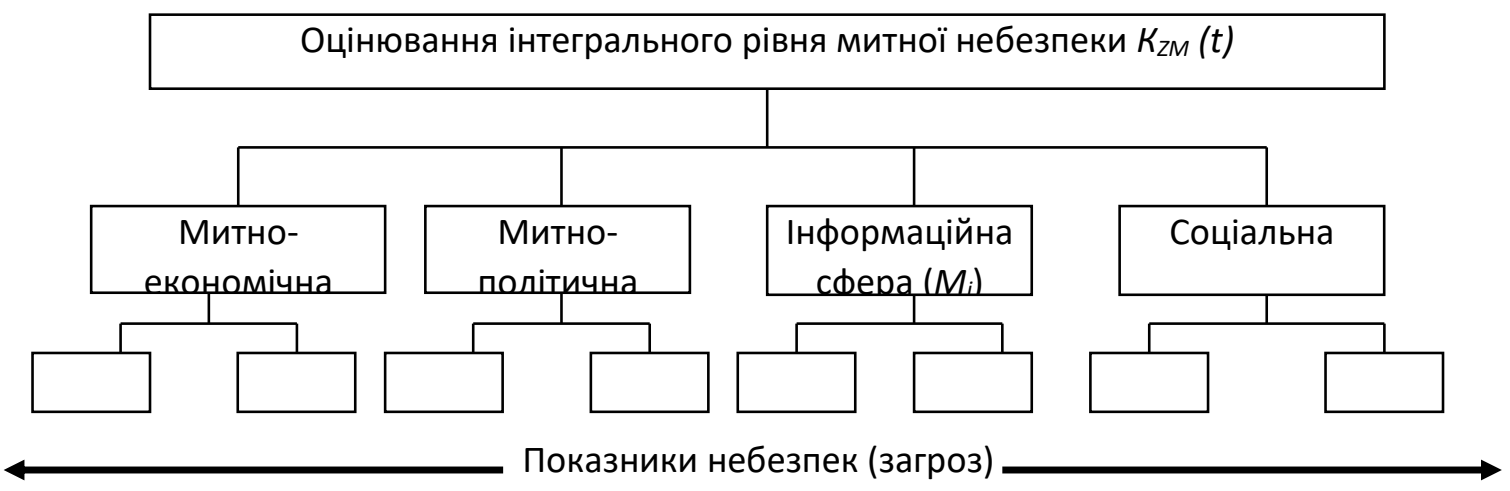

Рисунок 2 - Трирівнева ієрархія оцінювання інтегрального рівня митної небезпеки $K_{Z M}(t)$

Оцінювання інтегрального рівня митної небезпеки (MH) на момент часу $t_{1}$ здійснюється по формулі:

$$
K_{Z M}\left(t_{1}\right)=F\left\{U_{M 1}\left(t_{1}\right), \ldots, U_{M S}\left(t_{1}\right)\right\},
$$

де $F\{*\}$ - знак функціоналу;

$U_{M 1}\left(t_{1}\right), \ldots, U_{M s}\left(t_{1}\right)$ - вектор показників загроз (небезпек) по кожній із $S$ сфер взаємовідносин, що описують стан митних відносин 3 вибраною для оцінювання державою, вплив якого може призвести до кризи в митних стосунках з цією державою.

Четвертий частковий прочес: обгрунтування рішення на зміну режиму митного контролю в системі забезпечення митної безпеки. В ході даного часткового сценарію визначається рівень митного протистояння з вибраною для оцінювання державою методом порівняння значень інтегрального рівня митної небезпеки $K_{Z M}(t)$ 3 граничними (пороговими) рівнями, які нормативно встановлені для режимів функціонування органів, що здійснюють митний контроль.

Результати порівняння доводяться до особи, що приймає рішення (ОПР) на встановлення (зміну) режиму функціонування митних органів щодо проведення митного контролю (МК).
П’ятий частковий прочес: вибір режиму митного контролю та порогових рівнів деескалації митної небезпеки. Моделювання даного сценарію обов'язкове для автоматизованого варіанту управління вибором режиму функціонування митних органів, що адаптуються до інтегрального рівня митної небезпеки, як це показано на рис. 3. По результатам оцінювання митної обстановки (МО) експертним методом визначаються відмітні пороги деескалації митної небезпеки:

$P_{1}$ - поріг підвищеної митної небезпеки;

Рпкмо - поріг передкризової митної обстановки;

$P_{2}$ - поріг настання кризи в митних відносинах з державою, що розглядається.

Методом порівняння отриманого інтегрального рівня митної небезпеки 3 визначеними відмітними порогами готуються рекомендації ОПР щодо вибору (зміни) режиму митного контролю.

Так, при $0 \leq K_{Z M}(t) \leq P_{1}$ пропонується режим взаємовигідної співпраці;

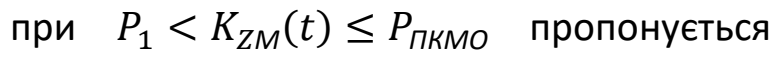
режим загострення митних відносин (підвищеної готовності митних органів);

при $P_{\text {пкмо }}<K_{Z M}(t) \leq P_{2}$ пропонується режим передкризової митної обстановки; 
при $P_{2}<K_{Z M}(t) \leq 1 \quad$ пропонується антикризовий режим.

Шостий частковий процес: розроблення (вибір) заходів щодо деескалації виявлених митних небезпек $і$ загроз та оцінювання їх прогнозного рівня. Реалізація даного часткового сценарію здійснюється фахівцями митного контролю. Фахівці митного контролю вибирають або відомі ефективні, або розробляють нові заходи щодо деескалації виявлених митних небезпек і загроз. Обов'язково проводиться оцінювання очікуваного рівня деескалації митної небезпеки. При наявності достатнього часу може проводитися незалежна зовнішня експертиза кожного пропонованого заходу.
Додатково можуть оцінюватися потрібні ресурси для реалізації вибраних або розроблених заходів щодо деескалації виявлених митних небезпек (загроз).

Сьомий частковий прочес: перевірка прогнозного інтегрального рівня митної небезпеки на достатність деескалації. Даний частковий сценарій реалізується низкою логічних процедур, які залежно від оціненого поточного інтегрального рівня митної небезпеки та вибраних порогів митної обстановки формують сигнал управління на переведення системи забезпечення митної безпеки (СЗМБ) у відповідний режим функціонування (див. рис. 3).

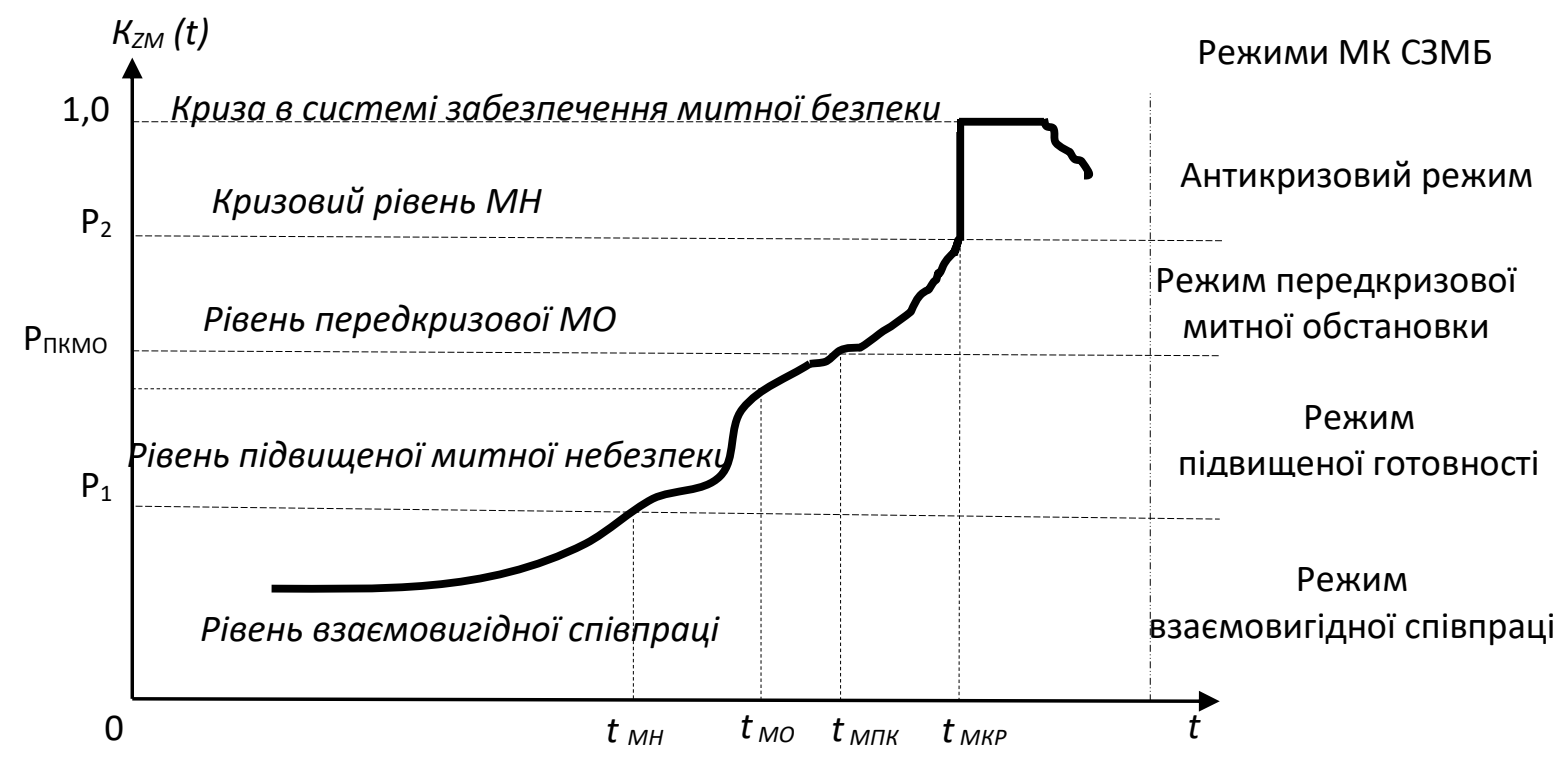

Рисунок 3 - До пояснення процесу адаптації системи забезпечення митної безпеки до інтегрального рівня митної небезпеки та вибору режиму митного контролю (розроблено авторами)

\section{Висновки}

Таким чином, застосування запропонованих рекомендацій щодо забезпечення митної безпеки на основі адаптації до інтегрального рівня митної небезпеки дають змогу не тільки визначати рівні митної небезпеки, зокрема: рівень взаємовигідної співпраці; рівень підвищеної митної небезпеки; рівень передкризової митної обстановки; рівень кризової митної обстановки, але і встановлювати кількісні значення порогів, що дає змогу системі забезпечення митної безпеки адаптуватися до величини інтегрального рівня митної небезпеки шляхом вибору того чи іншого режиму функціонування системи: режиму взаємовигідної співпраці; режиму підвищеної готовності; режиму передкризової митної обстановки, антикризового режиму. Це дає змогу підвищувати обгрунтованість управлінських рішень в системах забезпечення митної та економічної безпеки, підвищувати 
оперативність реагування на небезпеки і загрози митного та економічного характеру, більш раціонально використовувати наявні в системі людські та інші ресурси, в цілому підвищити ефективність забезпечення митної і економічної безпеки держави.

\section{Список використаних джерел}

1. Бережнюк І.Г. Розвиток системи митного регулювання України в умовах розширення міжнародного співробіт-ництва: автореф. дис. ... д-ра екон. наук : спец. 08.00 .02 “Світове господарство і міжнародні економічні відносини" / І.Г. Бережнюк. - К., 2009. -29 c.

2. Губа М. О. Місце митної безпеки держави серед основних складових їі забезпечення / М.О. Губа // Бізнес Інформ. - 2014. - № 11. C. 19-23.

3. Джумурат О. В. Місце та роль ризиків у системі митної безпеки держави / О.В. Джумурат // Вісн. Хмельницького нац. ун-ту. - Сер. “Економічні науки". - 2013. - № 3, T. 2. - С. 307-311.

4. Додін Є.В. Організація заходів протидії митній злочинності та митній делікатності / Є.В.Додін // Вісник Запорізького національного університету. - 2012. - № 1. С. 79-85.

5. Камчатная О. Таможенные интересы и таможенная безопасность как факторы обеспечения национальной безопасности Украины / О. Камчатная // Legea şi viaţa. 2014. - № 5. - C. 44-48.

6. Коляда С.П. Державна митна служба як суб'єкт забезпечення економічної безпеки України / С.П. Коляда // Стратегічні пріоритети. - 2007. - № 3. - С. 97-102.

7. Кочубей М. А. Безопасность в сфере таможенной деятельности: уголовноправовой и криминологический аспект / М.А. Кочубей. - М. :Закон и право, ЮНИТИДАНА, 2005. -255 c.

8 Куряков С. В. Проектирование системы управления в таможне по обеспечению финансовой безопасности : автореф. дис. ... канд.экон. наук / С.В. Куряков. - Саратов,
Перспективи подальшого дослідження полягають у розробленні, відповідно до викладеного матеріалу, методології оцінювання митної обстановки на основі кількісного визначення інтегрального рівня митної небезпеки.

9. Левко М. Системний підхід до визначення ролі і місця митної безпеки у забезпеченні економічної безпеки держави / М. Левко // Наук. вісн. Херсонського держ. ун-ту. - Сер. “Економічні науки". - 2015. - Вип. 15, частина 2. - С. 16-20.

10. Мартинюк В. П. Митна система та економічна безпека держави: теорія i методологія : монографія / В.П. Мартинюк. Тернопіль : Астон, 2010. - 256 с.

11. Новосад І. Роль митної безпеки в захисті національних інтересів держави / I. Новосад // Наук. вісн Східноєвропейського нац. ун-ту ім. Лесі Українки. - 2014. - № 14. - С. 20-25.

12. Пашко П.В. Організаційно-економічний механізм забезпечення митної безпеки України : автореф. дис. д-ра екон. наук : спец. 08.00.03 “Економіка та управління національним господарством" / П.В. Пашко. - Львів, 2009. -42 с.

13. Положення про Державну митну службу України, затверджене Указом Президента України від 08.02.97p. № 126/97 // www.customs. gov.ua.

14. Богданович В. Ю. Теоретико-методологічні основи забезпечення національної безпеки України: монографія. У 7 т. Т.1: Теоретичні основи, методи й технології забезпечення національної безпеки України / В.Ю. Богданович, І.Ю.Свида, Є.Д.Скулиш. - К.: Наук. вид. відділ НА СБ України, 2012.-548 с.

15. Богданович В.Ю. Теоретико-методологічні основи забезпечення національної безпеки України: монографія. У 7 т. Т.4: Воєнна безпека держави і шляхи їі забезпечення / В.Ю. Богданович, І.Ю. Свида, Є.Д. Скулиш. К.: Наук. вид. відділ НА СБ України, 2012. 464 c. 


\title{
Рекомендации по обеспечению таможенной безопасности на основе адаптации до интегрального уровня таможенной опасности
}

\author{
Владимир Богданович ${ }^{1 \mathrm{~A}}$; Иван Марко* 2 в; \\ Татьяна Яковлева ${ }^{3 \mathrm{C}}$; Сергей Саенко ${ }^{4 \mathrm{C}}$ \\ ${ }^{1}$ Доктор технических наук, профессор, главний научный сотрудник, e-mail: bogdnr11@gmail.com, ORCID: 0000-0003-0481-9454 \\ * Corresponding author: ${ }^{2}$ главный государственный инспектор, e-mail: i.marko94@gmail.com, ORCID:0000-0002-7208-3963 \\ ${ }^{3}$ слушатель кафедры экономики та финансового обеспечения, e-mail: yaktan@ukr.net, ORCID: 0000-0002-0595-2727 \\ ${ }^{4}$ слушатель кафедры экономики та финансового обеспечения, e-mail: saenkocznp@ukr.net, ORCID: 0000-0002-6713-1545 \\ А Центральный научно-исследовательский институт Вооруженных Сил Украины, г. Киев, Украина \\ в Государственная таможенная служба Украины, Киев, Украина \\ с Национальный университет обороны Украины имени Ивана Черняховского, Киев, Украина
}

\begin{abstract}
Аннотация
В статье рассматриваются рекомендации по обеспечению таможенной безопасности на основе адаптации к интегральному уровню таможенной опасности. Современная и будущая среда характеризуется широким спектром опасностей и угроз, обострением борьбы за доступ к новейшим высоким технологиям, ресурсам и рынкам сбыта, что деструктивно влияет на экономическую и таможенную безопасность государства. Предлагается провести декомпозицию опасностей и угроз по сферам проявления, построить трехуровневую модель оценки по технологии метода анализа иерархий и оценить интегральный уровень таможенной опасности на выбранный момент времени. Далее экспертным путем определяются отличительные уровни и пороги таможенной опасности, в частности: - уровень (порог) взаимовыгодного сотрудничества; уровень (порог) повышенной таможенной опасности; уровень (порог) предкризисной таможенной обстановки; уровень (порог) кризисной таможенной обстановки Это дает возможность системе обеспечения таможенной безопасности адаптироваться к величине интегрального уровня таможенной опасности путем выбора того или иного режима функционирования системы: режима взаимовыгодного сотрудничества; режима повышенной готовности; режима предкризисной таможенной обстановки, антикризисного режима При этом повышается обоснованность управленческих решений в системах обеспечения таможенной и экономической безопасности, повышается оперативность реагирования на опасности и угрозы таможенного и экономического характера, обеспечиваются условия для более рационального использования имеющихся в системе человеческих и других ресурсов и в целом повышается эффективность обеспечения таможенной и экономической безопасности государства.
\end{abstract}

Ключевые слова: таможня, опасность, угроза, таможенные органы.

\section{Recommendations for ensuring customs security based on adaptation to the integrated level of customs danger}

\author{
Vladimir Bohdanovych ${ }^{1}$ A; Ivan Marko* 2 B; \\ Tetiana Yakovlieva ${ }^{3}$; ; Serhii Saienko $4 \mathrm{C}$ \\ ${ }^{1}$ Dr of Technical Sciences, Professor, Chief Research Fellow, e-mail: bogdnr11@gmail.com, ORCID: 0000-0003-0481-9454 \\ * Corresponding author: ${ }^{2}$ Chief State Inspector, e-mail: i.marko94@gmail.com, ORCID:0000-0002-7208-3963 \\ ${ }^{3}$ student of the Department of Economics and Financial Support, e-mail: yaktan@ukr.net, ORCID: 0000-0002-0595-2727 \\ ${ }^{4}$ student of the Department of Economics and Financial Support, e-mail: saenkocznp@ukr.net, ORCID: 0000-0002-6713-1545

\footnotetext{
A Central Research Institute of the Armed Forces of Ukraine, Kyiv, Ukraine
} 
B State Customs Service of Ukraine, Kyiv, Ukraine

c National University of Defense of Ukraine named after Ivan Chernyiakhovskyi, Kyiv, Ukraine

\begin{abstract}
The article presents recommendations for customs security based on adaptation to the integrated level of customs danger. The current and future security environment is characterized by a wide range of dangers and threats, intensification of the struggle for access to the latest high technologies, resources and markets, which has a destructive effect on economic and customs security of the state. It is proposed to decompose hazards and threats by areas of manifestation, build a three-level model of assessment by the technology of hierarchical analysis and assess the integrated level of customs risk at the selected time. Then the distinctive levels and thresholds of customs danger are determined by expert means, in particular: the level (threshold) of mutually beneficial cooperation; level (threshold) of increased customs danger; level (threshold) of the pre-crisis customs situation; level (threshold) of the crisis customs situation. This allows the customs security system to adapt to the value of the integrated level of customs danger by choosing one or another mode of operation of the system: the mode of mutually beneficial cooperation; high alert mode; pre-crisis customs situation, anticrisis regime. This increases the validity of management decisions in customs and economic security systems, increases the efficiency of response to dangers and threats of customs and economic nature, provides conditions for more efficient use of human and other resources available in the system, and generally increases the efficiency of customs and economic security states.
\end{abstract}

Keywords: customs, danger, threat, customs authorities.

\title{
References
}

1. Berezhnyuk I. G. Rozvitok sistemi mitnogo regulyuvannya Ukrayini v umovah rozshirennya mizhnarodnogo spivrobitnictva [Development of the customs regulation system of Ukraine in the conditions of expansion of international cooperation]: PHD thesis abstract / I.G. Berezhnyuk. Kyiv, 2009. 29 p. [in Ukrainian]

2. Huba M. O. (2014). Mistse mytnoyi bezpeky derzhavy sered osnovnykh skladovykh yiyi zabezpechennya [The place of customs security of the state among the main components of its security]. Biznes Inform. № 11. Pp. 19-23. [in Ukrainian]

3. Dzhumurat O. V. (2013). Mistse ta rol' ryzykiv u systemi mytnoyi bezpeky derzhavy [The place and role of risks in the system of customs security of the state]. Visn. Khmel'nyts'koho nats. un-tu. Ser. "Ekonomichni nauky". № 3, T. 2. Pp. 307-311. [in Ukrainian]

4. Dodin YE.V. (2012). Orhanizatsiya zakhodiv protydiyi mytniy zlochynnosti ta mytniy deliktnosti [Organization of measures to combat customs crime and customs delinquency]. Visnyk Zaporiz'koho natsional'noho universytetu. № 1. Pp. 79-85. [in Ukrainian]

5. Kamchatnaya O. (2014). Tamozhennyye interesy i tamozhennaya bezopasnost' kak faktory obespecheniya natsional'noy bezopasnosti Ukrainy [Customs interests and customs security as factors providing of the national security of Ukraine]. Legea şi viaţa. № 5. Pp. 44-48. [in Russian]

6. Kolyada S. P. (2007). Derzhavna mytna sluzhba yak sub"yekt zabezpechennya ekonomichnoyi bezpeky Ukrayiny [State Customs Service as a subject of ensuring the economic security of Ukraine]. Stratehichni priorytety. № 3. Pp. 97-102. [in Ukrainian]

7. Kochubey M. A. (2005). Bezopasnost' v sfere tamozhennoy deyatel'nosti: ugolovnopravovoy i kriminologicheskiy aspekt [Security in the field of customs activity: criminal law and criminological aspect]. Moscow : Zakon i pravo, YUNITI-DANA, 255 p. [in Russian]

8 Kuryakov S. V. Proyektirovaniye sistemy upravleniya $v$ tamozhne po obespecheniyu 
finansovoy bezopasnosti [Designing a management system in customs to ensure financial security] : PhD thesis abstract / S.V. Kuryakov. Saratov, 2007. 20 p. [in Russian]

9. Levko M. (2015). Systemnyy pidkhid do vyznachennya roli i mistsya mytnoyi bezpeky u zabezpechenni ekonomichnoyi bezpeky derzhavy [System approach to determining the role and place of customs security in ensuring the economic security of the state]. Nauk. visn. Khersons'koho derzh. un-tu. Ser. "Ekonomichni nauky". № 15, part 2. Pp. 1620. [in Ukrainian]

10. Martynyuk V.P. Mytna systema ta ekonomichna bezpeka derzhavy: teoriya i metodolohiya : monograph [Customs system and economic security of the state: theory and methodology].Ternopil' : Aston, 2010. 256 p. [in Ukrainian]

11. Novosad I. (2014). Rol' mytnoyi bezpeky v zakhysti natsional'nykh interesiv derzhavy [The role of customs security in the protection of national interests of the state]. Nauk. visn Skhidnoyevropeys'koho nats. untu im. Lesi Ukrayinky. № 14. Pp. 20-25. [in Ukrainian]

12. Pashko P.V. Orhanizatsiyno-ekonomichnyy mekhanizm zabezpechennya mytnoyi bezpeky Ukrayiny [Organizational and economic mechanism for ensuring customs security of Ukraine] : PHD thesis abstract / P.V. Pashko. L'viv, 2009. 42 p. [in Ukrainian]
13. Regulations on the State Customs Service of Ukraine, approved by the Decree of the President of Ukraine dated 08.02.97. № 126/97. Available from: www.customs. gov.ua. [in Ukrainian]

14. Bohdanovych V. YU. Teoretykometodolohichni osnovy zabezpechennya natsional'noyi bezpeky Ukrayiny [Theoretical and methodological foundations of ensuring the national security of Ukraine] : monohraph. In 7 vols. Vol. 1: Teoretychni osnovy, metody y tekhnolohiyi zabezpechennya natsional'noyi bezpeky Ukrayiny [Theoretical foundations, methods and technologies of ensuring the national security of Ukraine] / V. YU. Bohdanovych, I. YU. Svyda, YE. D. Skulysh. Kyiv: Nauk. vyd. viddil NA SB Ukrayiny, 2012. 548 p. [in Ukrainian]

15. Bohdanovych V. YU. Teoretykometodolohichni osnovy zabezpechennya natsional'noyi bezpeky Ukrayiny [Theoretical and methodological foundations of ensuring the national security of Ukraine]: monohraph. In 7 vols. Vol. 4: Voyenna bezpeka derzhavy i shlyakhy yiyi zabezpechennya [Military security of the state and ways to ensure it] / V.YU.Bohdanovych, I. YU. Svyda, YE. D. Skulysh. Kyiv: Nauk. vyd. viddil NA SB Ukrayiny, 2012. 464 p. [in Ukrainian] 